\title{
PENERAPAN MODEL PEMBELAJARAN KOOPERATIF TIPE JIGSAW UNTUK MENINGKATKAN KEMAMPUAN MENULIS SURAT RESMI SISWA KELAS VIII MTsS MUALLIMIN BARABAI KABUPATEN HULU SUNGAI TENGAH
}

\author{
Rusidah \\ MTsS Muallimin Barabai \\ J1. Muallimin, Barabai Darat, Kecamatan Barabai \\ Kabupaten Hulu Sungai Tengah \\ Email: rusidahA2B111038@gmail.com
}

\begin{abstract}
Abstrak
Latar belakang penelitian ini adalah kemampuan menulis surat resmi merupakan salah satu keterampilan berbahasa pada pembelajaran bahasa dan sastra Indonesia dalam kurikulum di sekolah menengah pertama (SMP). Jika ditelusuri dalam kenyatannya, masih banyak ditemui kekurangan dalam penulisan surat resmi. Tujuan penelitian ini adalah (1) mendeskripsikan penggunaan model pembelajaran tipe jigsaw dapat meningkatkan kemampuan menulis surat resmi siswa kelas VIII MTsS Muallimin Barabai Kabupaten Hulu Sungai Tengah, (2) memaparkan aktivitas guru dan siswa kelas VIII MTsS Muallimin Barabai Kabupaten Hulu Sungai Tengah dalam pembelajaran menulis surat resmi dengan menggunakan model pembelajaran tipe jigsaw, (3) mengungkapkan respons siswa kelas VIII MTsS Muallimin Barabai Kabupaten Hulu Sungai Tengah dalam pembelajaran menulis surat resmi dengan menggunakan model pembelajaran tipe jigsaw.

Jenis penelitian yang dilakukan adalah Penelitian Tindakan Kelas, setting penelitian di MTsS Muallimin Barabai Kabupaten Hulu Sungai Tengah kelas VIII semester II dengan jumlah siswa 25 orang laki-laki. Faktor yang diteliti adalah faktor siswa, guru dan hasil belajar. Teknik pengumpulan yang digunakan yakni tes dan observasi. Alat pengumpulan data meliputi soal tes dan lembar observasi. Data dianalisis dengan teknik rumus persentase. Berdasarkan analisis dan interpretasi data maka diperoleh hasil penerapan model pembelajaran kooperatif tipe jigsaw untuk meningkatkan kemampuan menulis surat resmi siswa kelas VIII MTsS Muallimin Barabai Kabupaten Hulu Sungai Tengah sebagai berikut: (1) penerapan model pembelajaran kooperatif tipe jigsaw untuk meningkatkan kemampuan menulis surat resmi siswa kelas VIII MTsS Muallimin Barabai Kabupaten Hulu Sungai Tengah pada pertemuan siklus I pertemuan pertama yang tuntas sebanyak 13 orang siswa (52\%) dengan jumlah nilai sebesar 1.535 dengan rata-rata 61,4 meningkat pada siklus II yang tuntas sebanyak 25 orang siswa (100\%) dengan junlah nilai 1.910 dengan ratarata 76,4. Hasil belajar tersebut dapat dijadikan indikator keberhasilan penelitian tindakan kelas ini sehingga penelitian berakhir pada siklus II ini, (2) penerapan model pembelajaran tipe jigsaw dapat meningkatkan kemampuan menulis surat resmi, aktivitas siswa, dan kinerja guru dalam menulis surat resmi. Adanya peningkatan aktivitas siswa dalam menulis surat resmi dengan model pembelajaran tipe jigsaw pada siklus I dengan aktivitas siswa 55,2 (55\%) pada siklus I, dan 96 (96\%) pada siklus II. Adanya peningkatan kinerja guru dari hasil rata-rata skor $66 \%$ pada siklus I menjadi $100 \%$ pada siklus II. Jadi meningkat 44\% dari rata-rata skor siklus senelumnya, (3) respons siswa terhadap mata pelajaran bahasa Indonesia pada materi menulis surat resmi menunjukkan respon yang sebagian besar siswa atau $75 \%$ siswa menyenangi mata pelajaran bahasa Indonesia terutama pada materi menulis surat resmi.
\end{abstract}

Kata kunci: penerapan, kooperatif, jigsaw, kemampuan, menulis, surat resmi 


\section{Pendahuluan}

Surat resmi disebut juga surat dinas. Surat resmi merupakan sebuah kombinasi tertulis yang menyangkut kepentingan tugas dan kegiatan dinas instansi. Bahasa yang digunakan dalam surat resmi adalah baku, bentuknya juga formal mengikuti aturan yang diterapkan oleh instansi kedinasan. Surat resmi adalah surat yang digunakan dalam kegiatan kedinasan, perniagaan, atau perindustrian, baik oleh instansi pemerintah maupun oleh swasta. Isi surat resmi antara lain berupa pemberian tugas, pemberitahuan, permohonan, perintah, peringatan, panggilan, perjanjian, dan laporan (Pardjimin, 2005:45).

Sehubungan dengan itu, menulis surat resmi merupakan salah satu bagian dalam pembelajaran mata pelajaran bahasa dan sastra Indonesia. Menulis surat resmi merupakan hal yang sering dianggap sulit dan membosankan karena kendala-kendala yang dihadapi. Diantaranya dari kemampuan guru, kemampuan siswa, dan metode pembelajaran, situasi dan kondisi pembelajaran, dan sebagainya.

Berdasarkan KTSP mata pelajaran bahasa dan sastra Indonesia, menulis surat resmi terdapat di kelas VIII semester II dalam kompetensi dasar menulis surat resmi berkenaan dengan kegiatan sekolah dengan sestematika yang tepat dan bahan baku. Untuk itu, siswa kelas VIII khususnya kelas VIII MTsS Muallimin Barabai Kabupaten Hulu Sungai Tengah diajarkan menulis surat resmi berkenaan kegiatan dengan kegiatan sekolah.

Tujuan penelitian ini dapat dicapai dengan cara melakukan berbagai tindakan untuk memecahkan berbagai macam permasalahan pembelajaran di kelas yang selama ini dihadapi, baik disadari atau mungkin tidak disadari. Oleh karena itu, fokus penelitian tindakan kelas ini adalah terletak pada tindakan-tindakan alternatif yang direncenakan guru, kemudian dicobakan dan dievaluasi untuk mengetahui afektivitas tindakan-tindakan alternatif itu dalam memecahkan masalah pembelajaran yang dihadapi guru.

Berdasarkan informasi dari guru Bahasa Indonesia bahwa pembelajaran penulisan surat resmi dengan model pembelajaran kooperatif tipe jigsaw yang terprogram belum pernah diterapkan pada siswa sebelumnya, khususnya siswa kelas VIII semester II. Oleh karena itu, dengan menerapkan akan lebih dapat memberikan kemudahan siswa kelas VIII MTsS Muallimin Barabai Kabupaten Hulu Sungai Tengah dalam meningkatkan kemampuan menulis surat resmi.

Pada aspek inovasi pembelajaran, guru perlu memiliki keinginan untuk senantiasa mengubah, mengembangkan, meningkatkan gaya mengajarnya agar mampu menghasilkan model pembelajaran yang sesuai dengan tuntutan kelasnya. Penelitian ini berangkat dari realitas kegiatan guru, dalam prosesnya sangat terbuka bagi guru untuk merumuskan masalahnya sendiri.

Pembelajaran menulis surat resmi dengan model pembelajaran kooperatif tipe jigsaw merupakan alternatif untuk dapat memudahkan dan menunjang siswa dalam peningkatan 
kemampuan menulis surat resmi. Setelah memahami benar kegiatan penulisan surat resmi dengan model pembelajaran kooperatif tipe jigsaw tersebut, siswa akan dapat menerapkan sendiri sesuai dengan kemampuannya masing-masing. Siswa tingkat SMP/MTs akan dapat menyampaikan informasi melalui surat resmi untuk kepentingannya sendiri maupun organisasinya.

Hasil diskusi dengan guru bahasa Indonesia menunjukkan bahwa pembelajaran penulisan surat resmi dengan model pembelajaran kooperatif tipe jigsaw membuat siswa mempunyai gambaran dan minat yang tinggi dalam mempelajari surat resmi dan fungsinya.

Bimbingan guru yang baik dan menyenangkan akan menarik perhatian siswa, dan menjadikan kelancaran dan kemudahan dalam membuat surat resmi. Dengan melihat dan mengamati contoh sebuah surat resmi diharapkan kemampuan siswa dapat berkembang walaupun ketika menulis surat resmi masih sangat kurang. Kelemahan siswa dalam menulis surat resmi antara lain kemampuan untuk mengungkapkan idenya belum berkembang dan harus berpikir lama dalam menulis surat tanpa bantuan model pembelajaran kooperatif tipe jigsaw.

\section{Metode}

Pelaksanaan penelitian tindakan kelas ini dilaksanakan di MTsS Muallimin Barabai Kabupaten Hulu Sungai Tengah. Subjek penelitian ini adalah siswa kelas VIII MTsS Muallimin Barabai Kabupaten Hulu Sungai Tengah yang berjumlah 25 orang laki-laki.

Pendekatan penelitian ini adalah pendekatan kualitatif, sedangkan jenis penelitian yang akan diterapkan adalah penelitian tindakan kelas. Menurut Arikunto (2012:3), penelitian tindakan kelas adalah suatu pencermatan terhadap kegiatan belajar berupa sebuah tindakan, yang sengaja dimunculkan dan terjadi dalam sebuah kelas secara bersamaan. Penelitian tindakan ini diharapkan mampu memperoleh hasil kemampuan menulis surat resmi siswa yang dirumuskan dalam tujuan pembelajaran yaitu mengungkapkan pikiran dan perasaan melalui kegiatan menulis surat resmi. Penelitian tindakan kelas ini melibatkan guru mata pelajaran yang berperan sebagai rekan dalam mendiskusikan tindakan yang akan dilakukan atau subjek pengamatan, sedangkan peneliti berperan sebagai pengamat.

Model penelitian tindakan kelas ini menggunakan empat langkah dalam satu siklus, yaitu: 1) perencanaan, 2) aksi atau tindakan, 3) observasi, dan 4) refleksi.

Faktor-faktor yang diteliti

1. Faktor siswa yaitu pengamatan kegiatan belajar siswa dalam melaksanakan pembelajaran terhadap materi menulis surat resmi dengan menggunakan model pembelajaran kooperatif tipe jigsaw. Hal ini dapat terlihat bagaimana perhatian, keaktifan siswa, kerjasama dan kemampuan berpendapat serta keterampilan dalam pembelajaran melalui lembar pengamatan yang dibuat oleh guru. 
2. Faktor guru yaitu hasil pengamatan dalam pembelajaran bahasa Indonesia pada pembelajaran menulis surat resmi dengan menggunakan model pembelajaran kooperatif tipe jigsaw. Aktivitas guru dalam melaksanakan pembelajaran, penyampaian materi pelajaran, memberikan petunjuk dan arahan kepada siswa tentang langkah-langkah pembelajaran. Hasil pengamatan dengan menggunakan lembar observasi guru.

3. Faktor hasil belajar yaitu pengukuran hasil belajar siswa melalui tes tertulis diakhiri pelajaran yang dilakukan oleh guru. Kemudian hasil tes tersebut akan dinilai dan dianalisis sebagai acuan guru dalam melakukan penelitian.

\section{Skenario Tindakan}

Skenario tindakan pada penelitian ini akan dilaksanakan dua siklus. Setiap siklus meliputi tahapan-tahapan yang saling berkaitan dan berkesinambungan, yaitu perencanaan (planning) adalah mengembangkan rencana tindakan yang secara kritis untuk meningkatkan apa yang terjadi, pelaksanaan / tindakan (action) adalah tindakan yang dilakukan secara sadar dan terkendali, yang merupakan variasi praktik yang cermat dan bijaksana, pengamatan (observasi) berfungsi untuk mendokumentasikan pengaruh tindakan terkait dan kegiatan pengumpulan data yang berupa proses perubahan kinerja proses belajar mengajar, refleksi (reflection) adalah mengingat dan merenungkan suatu tindakan persis seperti yang telah dicatat dalam observasi. Refleksi berusaha memahami proses, masalah, persoalan, dan kendala yang nyata dalam tindakan strategis (Kunandar, 2011: 71$75)$.

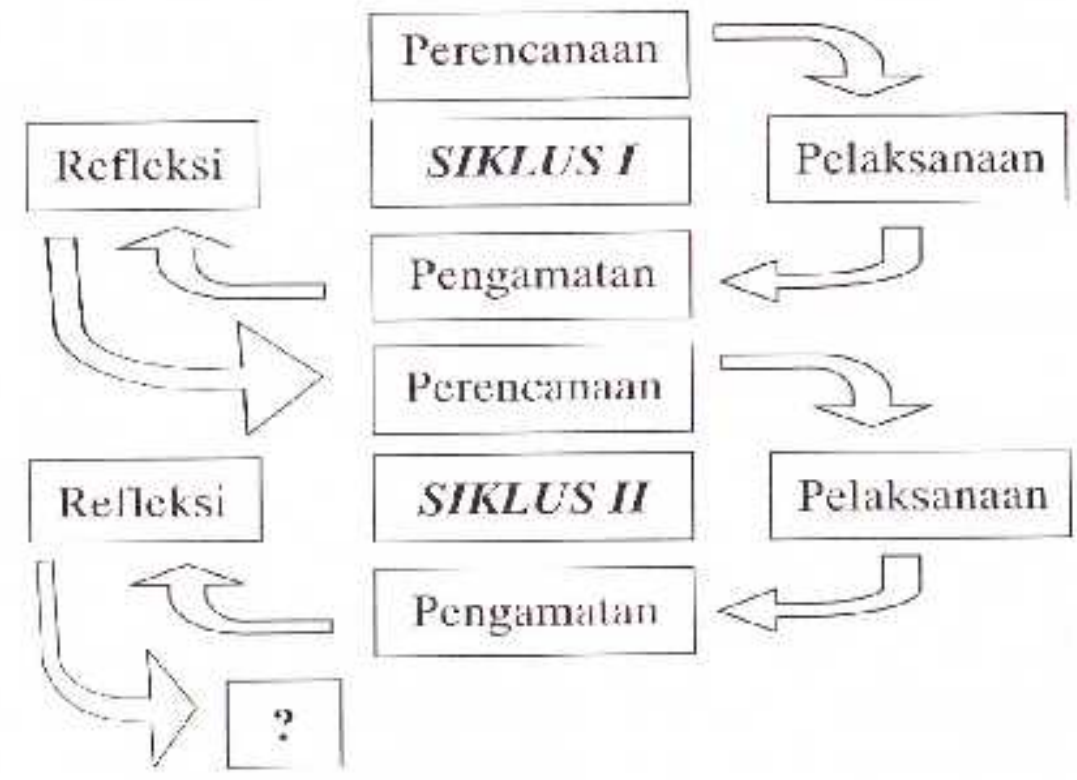

(Arikunto, 2012: 16) 


\section{Tindakan Siklus I}

Bagian-bagian dalam tindakan siklus I adalah sebagai berikut.

\section{Perencanaan}

Persiapan dalam perencanaan yang dilakukan untuk pelaksanaan Penelitian Tindakan Kelas, antara lain sebagai berikut.

a. Membuat rencana pelaksanaan pembelajaran

b. Peneliti melakukan analisis kurikulum untuk mengetahui kompetensi dasar yang akan disampaikan kepada siswa

c. Membuat media pembelajaran dalam rangka implementasi PTK.

d. Membuat lembar kerja siswa

e. Membuat instrumen yang digunakan dalam siklus PTK

f. Menyusun alat evaluasi pembelajaran.

\section{Pelaksanaan Tindakan}

Pelaksanaan tindakan yaitu deskripsi tindakan, skenario kerja tindakan perbaikan dan prosedur tindakan yang akan diterapkan.

a. Guru mengucapkan salam

b. Guru memeriksa kebersihan kelas

c. Guru memeriksa kehadiran siswa

d. Guru memberikan pre test untuk menjajaki pemahaman awal siswa

e. Siswa dikelompokkan ke dalam $=4$ anggota tim

f. Tiap orang dalam tim diberi bagian materi yang berbeda

g. Tiap orang dalam tim diberi bagian materi yang ditugaskan

h. Anggota dari tim yang berbeda yang telah mempelajari bagian/sub bab yang sama bertemu dalam kelompok baru (kelompok ahli) untuk mendiskusikan sub bab mereka

i. Setelah selesai diskusi sebagai tim ahli tiap anggota kembali ke kelompok asal dan bergantian mengajar teman satu tim mereka tentang sub bab yang mereka kuasai dan tiap anggota lainnya mendengarkan dengan sungguh-sungguh

j. Tiap tim ahli mempresentasikan hasil diskusi

k. Guru memberi evaluasi

1. Guru memberikan penghargaan individu dan kelompok

m. Guru bersama siswa melakukan refleksi 
n. Guru bersama siswa menyimpulkan pelajaran

o. Guru memberi tugas rumah

\section{Observasi}

Observasi yaitu prosedur perekaman data mengenai proses dan implementasi tindakan yang dirancang. Penggunaan instrumen yang telah disiapkan sebelumnya perlu diungkap secara rinci dan lugas termasuk cara perekamannya.

\section{Analisis dan Refleksi}

Prosedur analisis terhadap hasil pemantauan dan refleksi berkaitan dengan proses dan dampak tindakan perbaikan yang dilaksanakan, serta kriteria dan rangcangan bagi tindakan siklus berikutnya.

Data penelitian tindakan kelas ini dikumpulkan dari guru mata pelajaran Bahasa Indonesia dan siswa kelas VIII MTsS Muallimin Barabai Kabupaten Hulu Sungai Tengah.

Teknik pengumpulan data yang digunakan meliputi:

a. Test, teknik ini digunakan untuk memperoleh data tingkat pemahaman siswa yang telah dicapai selama proses pembelajaran dengan menggunakan model pembelajaran kooperatif tipe Jigsaw.

b. Observasi, teknik ini digunakan untuk memperoleh data tentang aktivitas siswa dalam belajar dan aktivitas guru dalam menggunakan medel pembelajaran kooperatif tipe Jigsaw.

c. Angket, teknik ini digunakan untuk memperoleh data tentang tanggapan dan pendapat siswa terhadap kegiatan pembelajaran dengan menggunakan model pembelajaran kooperatif tipe Jigsaw.

\section{Teknik Analisis Data}

a. Analisis data kualitatif

Teknik analisis ini digunakan untuk menganalisis hasil observasi aktivitas guru dan siswa serta gejala-gejala yang timbul pada saat berlangsungnya kegiatan pembelajaran dan hasil penyebaran angket (kuesioner) terhadap sikap dan pendapat siswa terhadap Kegiatan Belajar Mengajar (KBM) yang telah berlangsung.

b. Analisis data kuantitatif

Teknik ini digunakan untuk menganalisis data hasil belajar siswa berupa hasil tes yang diberikan. Analisis data ini diawali dengan kegiatan pemberian skor terhadap sejumlah pertanyaan 
atau soal yang diajukan. Selanjutnya skor yang diperoleh dianalisis dengan sistem penilaian agar diketahui tingkat pemahaman atau ketuntasan belajar siswa. Analisis tersebut dapa dilakukan dengan menghitung ketuntasan individual dan ketuntasan klasikal dengan rumus sebagai berikut :

Ketuntasan individual $=\frac{\text { jumlah skor }}{\text { jumlah skormaksima }} \times 100 \%$

Ketuntasan klasikal = $=\frac{\text { jumlah riss ysugrcuntas belajar }}{\text { jumlah skorseluruhnyg }} \times 100 \%$

Indikator Keberhasilan

Penelitian ini dikatakan berhasil jika memenuhi ketentuan berikut:

a. Ketuntasan belajar individu tercapai bila siswa tersebut mendapat nilai $\geq 65$ sesuai dengan Kriteria Ketuntasan Minimal (KKM) dari pihak MTsS Muallimin Barabai Kabupaten Hulu Sungai Tengah

b. Ketuntasan belajar siswa secara klasikal tercapai bila terdapat $85 \%$ siswa yang memperoleh nilai $\geq 78,8$ sesuai ketentuan Kriteri Ketuntasan Minimal dari pihak MTsS Muallimin Barabai Kabupaten Hulu Sungai Tengah.

c. Keaktifan siswa dalam proses belajar mengajar minimal baik dengan 10 kriteria observasi aktivitas siswa.

d. Keaktifan guru dalam proses belajar mengajar minimal baik dengan skor 15 kriteria observasi aktivitas guru.

e. Respon siswa terhadap kegiatan belajar mengajar pada pembelajaran menulis surat resmi pembelajaran tipe jigsaw.

\section{Hasil Penelitian dan Pembahasan}

\section{Analisis Hasil Tindakan}

Dari seluruh rangkaian pelaksanaan pembelajaran bahasa Indonesia siswa kelas VIII MTsS Muallimin Barabai Kabupaten Hulu Sungai Tengah siklus I baik pertemuan pertama maupun pertemuan kedua dan siklus II pada pertemuan pertama menggunakan model pembelajaran kooperatif tipe jigsaw dapat disimpulkan peningkatan yang signifikan pelaksanaan pembelajaran oleh guru dan peningkatan aktivitas dan hasil belajar siswa.

1. Perbandingan Pelaksanaan Pembelajaran Siklus I Dan Siklus II

Perbandingan Hasil Observasi Pembelajaran Kooperetif Tipe Jigsaw Pertemuan Siklus I dan Siklus II

\begin{tabular}{|c|c|c|c|c|c|c|c|}
\hline \multirow{2}{*}{ No } & \multirow{3}{*}{ Kategori } & \multicolumn{4}{|c|}{ Siklus i } & \multicolumn{2}{c|}{ Siklus ii } \\
\cline { 3 - 8 } & & \multicolumn{2}{|c|}{ Pertemuan 1 } & \multicolumn{2}{c|}{ Pertemuan 2 } & \multicolumn{2}{c|}{ Pertemuan 1 } \\
\cline { 3 - 8 } & & F & \% & F & \% & F & \% \\
\hline 1 & Ya & 10 & 66 & 12 & 80 & 15 & 100 \\
\hline
\end{tabular}




\begin{tabular}{|c|c|c|c|c|c|c|c|}
\hline 2 & Tidak & 5 & 44 & 3 & 20 & 0 & 0 \\
\hline \multicolumn{2}{|c|}{ Jumlah } & 15 & 100 & 15 & 100 & 15 & 100 \\
\hline
\end{tabular}

2. Perbandingan Aktivitas Murid Siklus I Dan Siklus II

Hasil analisis perbandingan frekuensi dan persentasi aktivitas siswa kelas VIII MTsS Muallimin Barabai Kabupaten Hulu Sungai Tengahmenggunakan model pembelajaran jigsaw masing-masing siklus dapat dilihat pada tabel berikut ini.

\section{Perbandingan Hasil Observasi Aktivitas Siswa pada Pembelajaran Kooperatif Tipe Jigsaw Siklus I dan Siklus II}

\begin{tabular}{|l|c|c|c|c|c|c|}
\hline \multirow{2}{*}{ Aktivitas } & \multicolumn{3}{c|}{ Siklus I } & \multicolumn{2}{c|}{ Siklus II } \\
\cline { 2 - 8 } & $\begin{array}{c}\text { Pertemuan } \\
\text { I }\end{array}$ & $\begin{array}{c}\text { Pertemuan } \\
\text { II }\end{array}$ & Pertemuan I \\
\cline { 2 - 8 } & F & $\%$ & F & $\%$ & F & $\%$ \\
\hline $\begin{array}{l}\text { Memperhatikan penjelasan guru materi } \\
\text { tentang menulis surat resmi }\end{array}$ & 15 & 60 & 20 & 80 & 25 & 100 \\
\hline Bertanya materi menulis surat resmi & 12 & 48 & 19 & 76 & 24 & 96 \\
\hline $\begin{array}{l}\text { Menjawab materi tentang menulis surat } \\
\text { resmi }\end{array}$ & 13 & 52 & 19 & 76 & 25 & 100 \\
\hline $\begin{array}{l}\text { Siswa berkelompok dengan tertib pada saat } \\
\text { pembelajaran berlangsung }\end{array}$ & 18 & 72 & 20 & 80 & 25 & 100 \\
\hline $\begin{array}{l}\text { Aktif mengerjakan LKS materi tentang } \\
\text { menulis surat resmi }\end{array}$ & 20 & 80 & 21 & 84 & 22 & 88 \\
\hline $\begin{array}{l}\text { Siswa aktif mengkomunikasikan hasil } \\
\text { jawaban }\end{array}$ & 12 & 48 & 20 & 80 & 22 & 88 \\
\hline Siswa melaksanakan evaluasi & 18 & 72 & 22 & 88 & 25 & 100 \\
\hline Siswa melakukan refleksi & 18 & 72 & 20 & 80 & 22 & 88 \\
\hline Menyimpulkan materi pelajaran & 0 & 0 & 20 & 80 & 25 & 100 \\
\hline Mancatat tugas di rumah & 48 & 20 & 80 & 25 & 100 \\
\hline
\end{tabular}

\section{Perbandingan Hasil Belajar Siklus I dan Siklus II}

Hasil analisis perbandingan frekuensi dan persentasi hasil belajar Bahasa Indonesia siswa kelasVIII MTsS Muallimin Barabai Kabupaten Hulu Sungai Tengahmenggunakan model pembelajaran kooperatif tipe jigsaw masing-masing siklus dapat dilihat pada tabel berikut ini. 


\section{Perbandingan Hasil Pembelajaran Kooperatif Tipe Jigsaw Siklus I Dan Siklus II}

\begin{tabular}{|c|c|c|c|c|}
\hline \multirow[b]{2}{*}{ No } & \multirow[b]{2}{*}{ Nama } & \multicolumn{2}{|c|}{ Nilai } & \multirow[b]{2}{*}{ Selisih } \\
\hline & & $\begin{array}{c}\text { Tanpa Model } \\
\text { Jigsaw }\end{array}$ & $\begin{array}{c}\text { Dengan Model } \\
\text { Jigsaw }\end{array}$ & \\
\hline 1 & Abdussyakur & 75 & 85 & 10 \\
\hline 2 & Aditya Akbar & 60 & 80 & 20 \\
\hline 3 & Akhmad Zaini Rahman & 55 & 75 & 20 \\
\hline 4 & Aswad Fadillah & 70 & 80 & 10 \\
\hline 5 & Faisal Sahbar & 65 & 70 & 5 \\
\hline 6 & Hamid Nur Mukhlis & 60 & 70 & 10 \\
\hline 7 & Hendrawan & 70 & 80 & 10 \\
\hline 8 & Irfan Riani & 50 & 80 & 30 \\
\hline 9 & M. Agus Misriadi & 50 & 85 & 35 \\
\hline 10 & M. Fahmi & 55 & 70 & 15 \\
\hline 11 & M. Hendri & 75 & 80 & 5 \\
\hline 12 & M. Ilham Nafarin & 65 & 75 & 10 \\
\hline 13 & M. Raihan & 50 & 70 & 20 \\
\hline 14 & M. Ramadhani & 75 & 70 & -5 \\
\hline 15 & M. Rizky & 70 & 70 & 0 \\
\hline 16 & M. Rizqi Fadhillah & 50 & 70 & 20 \\
\hline 17 & M. Salimi & 60 & 70 & 10 \\
\hline 18 & M. Sahrul Ramadhan & 55 & 80 & 25 \\
\hline 19 & M. Taufik & 70 & 75 & 5 \\
\hline 20 & M. Taufuk Rahman & 60 & 70 & 10 \\
\hline 21 & M. Yudi Fitriyadi & 50 & 80 & 30 \\
\hline 22 & M. Zulkifli & 65 & 85 & 20 \\
\hline 23 & Ridhani & 65 & 70 & 5 \\
\hline 24 & Salam & 60 & 75 & 15 \\
\hline 25 & Yudha Yulistiawan & 55 & 80 & 25 \\
\hline
\end{tabular}




\begin{tabular}{|c|c|c|c|c|} 
& Jumlah & 1535 & 1895 & 360 \\
\hline & Nilai rata-rata & 61.4 & 75.8 & 14.4 \\
\hline & Nilai maksimal & 75 & 85 & 10 \\
\hline & Nilai minimal & 50 & 70 & 20 \\
\hline
\end{tabular}

Uraian perbandingan frekuensi dan persentasi hasil belajar bahasa Indonesia siswa kelas VIII MTsS Muallimin Barabai Kabupaten Hulu Sungai Tengah menggunakan model pembelajaran jigsaw masing-masing siklus dapat dilihat pada tabel di atas. Dari perolehan hasil belajar siswa tergambar bahwa terjadi peningkatan di setiap pertemuan. Hal ini disebabkan oleh penggunaan model pembelajaran jigsaw dapat meningkatkan aktivitas dan hasil belajar bahasa Indonesia pada materi menulis surat resmi. Jadi dengan hasil tersebut dapat disimpulkan bahwa peneltian ini telah berhasil dilaksanakan.

\section{Simpulan}

Berdasarkan dari hasil pembelajaran dan pembahasan yang telah disajikan pada bab sebelumnya dapat diambil simpulan sebagai berikut:

1. Penerapan model pembelajaran kooperatif tipe jigsaw untuk meningkatkan kemampuan menulis surat resmi siswa kelas VIII MTsS Muallimin Barabai Kabupaten Hulu Sungai Tengah dilakukan dua siklus dengan 4 tahap yaitu: perencanaan, pelaksanaan, observasi, dan refleksi. Hal ini dibuktikan bahwa hasil belajar siswa kelas VIII MTsS Muallimin Barabai Kabupaten Hulu Sungai Tengah pada pertemuan siklus I pertemuan pertama yang tuntas sebanyak 13 orang siswa (52\%) dengan jumlah nilai sebesar 1.535 dengan rata-rata 61,4 meningkat pada pertemuan kedua yang tuntas sebanyak 21 orang siswa (100\%) dengan jumlah nilai 1.705 dengan nilai rata-rata 68,2. Pada pertemuan pertama siklus II yang tuntas sebanyak 25 orang siswa (100\%) dengan junlah nilai 1.910 dengan rata-rata 76,4. hasil belajar tersebut dapat dijadikan indikator keberhasilan penelitian tindakan kelas ini sehingga penelitian berakhir pada siklus II ini.

2. Penerapan model pembelajaran tipe jigsaw dapat meningkatkan kemampuan menulis surat resmi, aktivitas siswa, dan kinerja guru dalam menulis surat resmi. Adanya peningkatan aktivitas siswa kelas VIII MTsS Muallimin Barabai Kabupaten Hulu Sungai Tengah dalam menulis surat resmi dengan model pembelajaran tipe jigsaw pada tiap siklus. Peningkatan tersebut dapat dilihat dari hasil pengamatan aktivitas siswa dari siklus I sampai dengan siklus II, dengan nilai aktivitas siswa 55,2 pada siklus I, dan 96 pada siklus II. Adanya peningkatan 
aktivitas guru dari hasil persentase 55,2\% pada sklus I menjadi $96 \%$ pada siklus II. Jadi meningkat 40,8\% dari siklus sebelumnya.

3. Respons siswa terhadap mata pelajaran bahasa Indonesia pada materi menulis surat resmi menunjukkan respon yang sebagian besar siswa atau $75 \%$ siswa menyenangi mata pelajaran Bahasa Indonesia terutama pada materi menulis surat resmi.

\section{Saran}

Berdasarkan simpulan di atas, peneliti memberikan saran sebagai masukan yaitu:

1. Bagi Kepala Sekolah

Kepala sekolah merupakan penanggung jawab pendidikan, oleh karena itu jika terdapat guru yang ingin meningkatkan kualitas pendidikan dengan melakukan inovasi pembelajaran kepala sekolah harus mendukungnya. Dukungan kepala sekolah tidak hanya izin saja, akan tetapi menyediakan berbagai fasilitas dan media pembelajaran sebagai sarana untuk mengadakan inovasi pembelajaran.

2. Bagi Guru

Guru diharapkan dapat menerapkan model pembelajaran kooperatif tipe jigsaw dan juga metote kooperatif lainnya untuk meningkatkan kemampuan menulis surat resmi dalam kegiatan belajar.

3. Bagi Siswa

Siswa setidaknya berupaya secara optimal dalam meningkatkan aktivitas kegiatan pembelajaran untuk mendapatkan pengalaman yang berharga dalam belajar sehingga berhasil pembelajaran bahasa Indonesia yang maksimal.

\section{Daftar Rujukan}

Arifin, E. Zainal, S. Amran Tasai. 2006. Cermat Berbahasa Indonesia. Jakarta: Akademika Pressindo

Arikunto, Suharsimi. 2012. Penelitian Tindakan Kelas. Jakarta: Bumi Aksara

Darmawati, Uti. 2007. Surat Menyurat. Klaten: Macanan Jaya Cemerlang

Darmawati, Uti. 2009. Surat-surat Dinas. Klaten: PT Intan Pariwara

Kunandar. 2008. Langkah Mudah Penelitian Tinadakan Kelas Sebagai Pengembangan Profesi Guru. Jakarta: Rajawali Press.

Muryanto, A. Kristiawan. 2008. Panduan menulis Surat. Yogyakarta: PT Citra Aji Parama

Musaba, Zulkifli, Mohammad Siddik. 2010. Dasar-dasar Menulis. Malang: Mandiri 
Nugraheni, Aninditya Sri. 2012. Penerapan Strategi Cooperative Learning dalam Pembelajaran Bahasa Indonesia. Yogyakarta: Padagogia

Novi. 2008. Model Jigsaw. http: novi. Jurnal Ilmu pendidkan. (online). (http://www.modeljigsaw.ac.id, diakses 7 maret 2015)

Pardjimin. 2005. Bahasa dan Sastra Indonesia. Bogor: Yudhististira

Poerwadarminta. 2007. Kamus Besar Bahasa Indonesia. Jakarta : Balai Pustaka

Purwaningsih, Eko. 2007. Mengenal Surat Menyurat. Jakarta: Ganeca Exact

Prayito. 2012. Makalah Inovasi Pembelajaran Matematika Guna Memenuhi Tugas Inovasi Pembelajaran Matematika..(online) ( http: Prayitno. co.id di akses 7 Maret 2015)

Rachmawati, Fajar. 2009. Ragam Kalimat Non Sastra. Yogyakarta: Citra Aji $\quad$ Parama

Semi, M. Atar. 2007. Dasar-dasar Keterampilan Menulis. Bandung: Angkasa

Sudrajat, Ahmad. 2008. Pembelajaran Kooperatif(Cooperative Learning) Teknik Jigsaw. (Online). (http: sudrajat. co.id. di akses 7 Maret 2015)

Sunarti, Yani Maryani. 2007. Intisari Bahasa dan sastra Indonesia. Bandung: Pustaka Setia

Taniredja, Tukiran. 2012. Model-model Pembelajaran Inovatif. Bandung: Alfabeda

Triningsih, Diah Erna. 2009. Diksi (pilihan kata). Klaten: Intan Pariwara

Tim Penyusun. 2014. Pedoman Penulisan Skripsi. Banjarmasin: STKIP PGRI Banjarmasin 